\title{
Daha Fazla Güç Talebi Ölçeği'nin Geçerlik ve Güvenirlik Çalışması (Validity and Reliability Study of Higher Order Need Strength Scale)
}

\section{Kenan ORÇANLI iD a}

a Toros Üniversitesi İ̇SBF, İşletme Bölümü, Mersin, Türkiye. kenanorcanli@gmail.com

\begin{tabular}{|c|c|}
\hline MAKALE BİLGİSİ & ÖZET \\
\hline Anahtar Kelimeler: & Cl, Warr, Cook ve Wall (1979) tarafından geliștirilen ve İngilizcesi \\
\hline $\begin{array}{l}\text { Daha Fazla Güç Talebi } \\
\text { Geçerlik }\end{array}$ & $\begin{array}{l}\text { "Higher Order Need Strength Scale" olan "Daha Fazla Güç Talebi Ölçeği" ni Türkçeye uyarlamak ve } \\
\text { söz konusu ölçeğin geçerlik ve güvenirlik çalışmasını yapmaktır. }\end{array}$ \\
\hline
\end{tabular}

Güvenilirlik

Gönderilme Tarihi 3 Ocak 2021

Revizyon Tarihi 2 Haziran 2021

Kabul Tarihi 15 Haziran 2021

Makale Kategorisi: Araştırma Makalesi

Yöntem - Ölçeğin Türkçeye tercüme edilmesi ve uyarlanmasında Brislin (1970) tarafından önerilen yöntem, ölçeğin geçerliliğinin sağlanmasında uzman grubunun görüşlerinden yararlanarak ölçek kapsam geçerlik oranı ve indeksi istatistikleri, ölçeğin yapı geçerliğinin kontrol edilmesinde açıklayıcı ve doğrulayıcı faktör analizleri, güvenirlik analizi ile ilgili Cronbach alfa katsayısı ile madde analizi kullanılmıştır. Yapılan analizlerde ise on kişilik uzmandan elde edilen görüşlerden ve Ankara ve Mersin ili sinırlarında bulunan vakıf üniversitelerinde görevli 296 akademisyene uygulanması sonucunda elde edilen verilerden faydalanılmıştır.

Bulgular - Çalışmanın sonunda; açıklayıcı faktör analizinden elde edilen sonuçlara göre KMO değerinin 0,853 ve ölçeğin tek boyutlu olduğu, faktör yüklerinin 0,379-0,849 arasinda bulunduğu, toplam varyansın \% 59,853'nün açıklandığı,; doğrulayıcı faktör analizinden elde edilen istatistiklere göre uyum iyiliği değerlerinin Ki-kare:54,774, RMSEA:0,026, CFI:0,95, SRMR:0,035, TLI:0,917 olduğu ve hepsinin referans değerleri arasında bulunduğu tespit edilmiştir. Ayrıca güvenirlik analizinden elde edilen Cronbach's alfa katsayısının değeri ise 0,834 olarak bulunmuştur.

Tartışma - Bulunan değerler 1şı̆̆ında, “Daha Fazla Güç Talebi Ölçeği” nin Türkiye'de sosyal bilimler alanında yapılacak çalışmalar için geçerli olduğu ve güvenilir bir şekilde kullanılabileceği sonucuna ulaşılmıştır.

\section{ARTICLE INFO ABSTRACT}

Keywords:

Higher Order Need

Strength

Reliability

Validity

Received 3 January 2021

Revised 2 June 2021

Accepted 15 June 2021

Article Classification:

Research Article
Purpose - The aim of this study was to adapt the Higher Order Need Strength Scale developed by Warr, Cook and Wall (1979) to Turkish and to make the validity and reliability of the scale.

Design/methodology/approach - In this study, the method proposed by Brislin (1970) in the translation and adaptation of the scale into Turkish, the scale content validity rate and index statistics by using the opinions of the expert group in ensuring the validity of the scale, the explanatory and confirmatory factor analyzes in checking the construct validity of the scale, and the Cronbach alpha coefficient related to the reliability analysis. item analysis was used. In the analyzes made, the opinions obtained from ten experts and the data obtained as a result of the application to 296 academicians working at foundation universities in Ankara and Mersin provinces were used.

Findings - At the end of the study; according to the results obtained from the explanatory factor analysis, the KMO value was 0.853 and the scale was unidimensional, the factor loads were between $0.379-0.849$, and $59.853 \%$ of the total variance was explained; according to the statistics obtained from the confirmatory factor analysis, it was determined that the values of goodness of fit were Chi-square: 54,774, RMSEA: 0.026, CFI: 0.95, SRMR: 0.035, TLI: 0.917, and they were all within the reference values. In addition, the value of the Cronbach's alpha coefficient obtained from the reliability analysis was found to be 0,834 .

Discussion - The values found in the light, Higher Order Need Strength Scale is valid in studies conducted in Turkey has reached and the results can be used in a reliable way. 


\section{GİRIŞ}

Küreselleşme ve bilişim teknolojilerindeki gelişmeler dünyamızı şekillendirmekte, insanların bilgiye kolayca ulaşmasını sağlamaktadır. Bilgi toplumu, bilgi ekonomisi, toplum 5.0 gibi kavramlar sürekli gündemdedir ve tartışılmaktadır. Çünkü günümüzde bilgi her an eskimektedir, her an yenisi üretilmektedir. Bu durum da değişimi ve rekabeti artırmakta, insanı önemli bir unsur olarak karşımıza çıkarmaktadır. Bilgiyi üreten de kullanan da insandır. Dolayısıyla örgütün başarısı çalışanların niteliğine ve yaratıcılığına büyük ölçüde bağlı olmaktadır. Örgütün sadece nitelikli personele sahip olması yeterli değildir, ayrıca bu kişilerin örgüte bağlllığı ve sadakati ile iş tatmini de önemlidir. İnsanlar sorumluluk hissettikleri için çalışır; çalışma günleri insanlara bir miktar özerklik ve takdir yetkisi sunar (Schwartz, 2017: 1). Güç ihtiyacı da özerklik ve takdir yetkisi kapsamında değerlendirilmelidir. İş özellikleri modelini geliştiren Hackman ve Oldham (1975) da özerkliği herhangi bir işin beş temel faktöründen birisi olarak belirlemiştir. Özerklik, işin planlanması ve uygulanacak süreçlerin kararlaştırılması ile ilgili olarak çalışana özgürlük, bağımsızlık ve takdir yetkisi vermektir (Robbins ve Judge, 2012: 243). Diğer bir anlatımla özerklik, personelin yetkisinin ve sorumluluğunun artırılarak güçlendirilmesidir. İş özellikleri ile değerlendirildiğinde özerklik, insan davranışını etkileyen, onu çalışmaya yönlendiren, motive eden ve doyum sağlayan, performansı artıran, devamsızlığı azaltan önemli bir unsurdur (Bekmezci, 2017: 201).

Rekabetin çok şiddetli yaşandığı günümüzde de işletmeler için en önemli kaynak insandır ve örgütlerin başarılı olması için yöneticiler bu kaynaktan en üst seviyede faydalanmalıdır. Yenilik yapabilmek özgürlük gerektirir, verimliliği artırmak için de çalışanlar yönetim kararlarına daha fazla katılmalıdır (Çavuş, 2008: 1289). Ayrıca çalışanların müşteri taleplerine hızlı karşılık vermesi, esnek olması, risk alması gerekir ki; bu da yaratıcılığın teşvik edilmesine, yöneticilerin çalışanları desteklemesine ve işletmede bir güven ortamı yaratmasına bağlıdır (Coleman, 1996: 30). Ayrıca günümüzde bilgisayar ve iletişim teknolojileri sayesinde ihtiyaç duyulan bilgiye çok çabuk ulaşmak mümkündür. Nitekim yapılan araştırmalar neticesinde, şu anda iş dünyasına yeni giren ve kısa bir sürede yönetici pozisyonuna geçeceği değerlendirilen $Y$ kuşağı; bağımsız, girişimci, geri bildirim almaya istekli, kısa sürede başarı beklentisi içinde olan, özgürlügü ve esnekliği seven, makro yönetimden hoşlanmayan, bulunduğu ortamdaki eksiklik ve aksaklıkları hemen fark eden ve bunları düzeltmek için istek duyan kişiler olarak tanımlanmakta ve 2025 yılında dünyadaki iş gücünün \%75'ini oluşturacağı öngörülmektedir (Bekmezci, 2017: 105-106). Kısaca günümüz iş dünyasında çalışanlar kendisini güçlü hissettiğinde, gücü artırıldığında işinden tatmin olmaktadır. Dolayısıyla değişen koşullar çalışanlara daha fazla güç verilmesini ve daha fazla güç isteyen kişilerin istihdam edilmesini zorunlu hale getirmiştir. Bu kapsamda değerlendirildiğinde Warr vd. (1979) tarafından geliştirilen “Daha Fazla Güç Talebi” ölçeğinin günümüzde de güncelliğini koruduğu ifade edilebilir.

Daha fazla güç talebi, uluslararası yazında 1970-1990 arasında kendine ciddi bir yer bulmuş konulardan biridir. Bu dönemdeki çalışmalar, daha fazla güç talebinin, çalışanların iş tatmini ve performanslarını etkilediğini öne sürmüştür (Abdel Halim, 1980: 336; Porter ve Lawler, 1968; Hackman ve Lawler, 1971; Hackman ve Oldham, 1975). Daha fazla güç talebi, daha çok iş-insan arasındaki etkileşimi açıklamak için kullanılmakta olup, iş tasarımı, iş zenginleştirme gibi kavramlarla ilişkilidir (Hackman ve Oldham, 1975: 159). Hackman ve Lawler, daha fazla güç talebini, kişisel gelişim ve ilerleme ihtiyacı ya da önemli şeyler başarma duygusu olarak ifade etmiştir (Hackman ve Lawler, 1971: 262).

Daha fazla güç ihtiyacının kavramsal olarak ortaya çıkışı Maslow'un ihtiyaçlar hiyerarşisi ile Alderfer'in ERG kuramına uzanmaktadır. Alan yazında daha fazla güç talebi ile birlikte gelişme ihtiyacı (growth need strength) kavramının da kullanıldığı görülmektedir (Lin vd., 2018; Shalley vd., 2009; Cellar vd., 1992; Kemp ve Cook, 1983; Hackman ve Oldham, 1975) ve bu iki kavramın birbiri yerine kullanıldığı görülmekte fakat bazı görüşler daha fazla güç ihtiyacı kavramının, Maslow'un ihtiyaçlar hiyerarşisinde üst düzey ihtiyaç olarak belirttiği değer ihtiyacı ile kendini gerçekleştirme ihtiyacını daha iyi karşıladığını öne sürmektedir (Spector, 1985: 120).

Olgunun temel varsayımı, daha fazla güç talebini ortaya koyan çalı̧̧anların otonomi, çeşitlilik ve değer taşıyan yeteneklerin kullanılmasına imkân sunan işlerde tatmin düzeyinin daha yüksek olacağıdır (Pastor ve Erlandson, 1982: 173). İşle ilgili özellikler konusunda yazında Turner ve Lawrence, otonomi, çeşitlilik, gerekli etkileşim, opsiyonel etkileşim, gerekli bilgi ve beceri ve sorumluluğu ifade ederken Hackman ve Lawler, otonomi, çeşitlilik, iş kimliği ve geribildirimi ifade etmektedir (Ivancevich ve McMahon, 1977: 553; Hackman 
ve Lawler, 1971; Turner ve Lawrence, 1965). Daha sonra yapılan çalışmalardan Spector'ın çalışmasında bu özellikler boyut olarak ele alınmış ve işin yapılmasında kullanılan becerilerin çeşitliliği, yapılan işin kimliği, işin önemi, otonomi ve işin sonunda sağlanan geribildirim olarak ifade edilmiştir (Spector, 1985: 119).

\section{DAHA FAZLA GÜÇ TALEBINIIN ÖLÇÜMÜNE İLIŞKİN GELIŞTİRILMIŞ ÖLÇEKLER}

Yazında daha fazla güç talebinin operasyonel hale getirilmesinde iki temel yol izlenmiştir. İlki Hackman ve Lawler (1971)'ın ölçeğinde olduğu gibi çalışanların ideallerindeki iş ile ilgili ya da mevcut işlerinde sahip olmak istedikleri özelliklerin düzeyleri ile ilgili indekslerden oluşan özbildirim ölçekleridir. Bu ölçeklerde daha fazla güç talebi, iş özellikleri ile kişilerin işe yönelik tutumları arasındaki ilişkiden çıkarılmaktadır. İkinci yol ise Jackson (1967)'n Kişilik Araştırma Formu'nda uygulandığı gibi bireysel farklılıklara yönelik özbildirim ölçekleridir (Stone vd., 1979: 330). Yazında geliştirilmiş ölçeklerden olan Hackman ve Lawler (1971)'ı ölçeğinde 12 soru yer almakta olup, işleri ile ilgili sahip olmak istedikleri durumları açıklayan sorular bulunmaktadır. Yazarlar ölçeği "minimum düzeyde olmasını isterdim" ifadesinden "maksimum düzeyde olmasını isterdim" ifadesine uzanan 7'li Likert tipinde hazırlamışlar ve 0,89 güvenirlik değeri elde etmiştir (Hackman ve Lawler, 1971: 269-270). Hackman, Oldham ile yaptığı 1975 yılındaki çalışmasında toplamda 18 sorudan oluşan fakat farklı formatlarda ölçek hazırlamıştır. Ölçeğin bir boyutu, 1971 yılındaki çalışmasında olduğu gibi "istemek" (would like) formatında olup, 6 soru yer almaktadır ve güvenirlik değeri $0,88^{\prime}$ dir. Diğer boyutu ise iş seçimi formatında olup, 12 soru yer almaktadır ve güvenirlik değeri 0,71'dir (Hackman ve Oldham, 1975: 164). Warr ve arkadaşları da 1979 yılında bir ölçek geliştirmişlerdir. Ölçekte altı soru yer almakta olup, 200 ve 390 kişiden oluşan mavi yakalı erkek çalışanlar üzerinde yaptı̆̆ iki ayrı araştırma neticesinde güvenirlik değerlerini sırasıyla 0,91 ve 0,82 olarak tespit etmiş̧tir (Warr vd., 1979: 135).

\section{YÖNTEM}

\subsection{Araştırmanın Amacı}

Warr vd. (1979) tarafından geliştirilen "Daha Fazla Güç Talebi Ölçeği" ni Türkçeye uyarlamak ve söz konusu ölçeğin geçerlik ve güvenirlik çalışmasını yapmaktır.

\subsection{Araştırmanın Modeli}

Yapılan çalışmada araştırma modeli olarak tarama modeli seçilmiş, bu kapsamda ilk olarak literatür taraması yapılmış, müteakiben elde edilen veriler kullanılarak ölçeğin yapı geçerliğinde açılayıcı ve doğrulayıcı faktör analizi kullanılmış ve güvenirliğin sağlanmasında güvenirlik analizi (cronbach alfa) ile ilgili daha açıklayıcı istatistiki değerler hesaplanmıştır.

\subsection{Araştırmanın Evren ve Örneklemi}

Çalışmada ölçeğin geçerlik ve güvenirliğinin sağlanması maksadıyla yapılan analizlerde kullanılan veriler, Ankara ve Mersin ilinde bulunan vakıf üniversitelerinde görevli akademisyenlerden Kasım-Aralık 2019 döneminde alınan cevaplardan elde edilmiştir. Anket kolayda örnekleme yöntemine göre oluşturulmuş 350 kişilik örnekleme uygulanmış, ancak verilen cevapların incelenmesi neticesinde analize 296 kişi dâhil edilmiştir. Ankete katılan kişilerin doğru ve tarafsız bir şekilde soruları cevaplandırdığı değerlendirilmiştir. Ankete katılan 296 kişiye ait demografik bilgiler Tablo-1'de özetlenmiştir. 
Tablo 1. Ankete Katılanların Demografik Bilgileri

\begin{tabular}{|c|c|c|c|c|c|c|c|}
\hline Sinif & Özellik & f & $\%$ & Sinıf & Özellik & 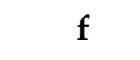 & $\%$ \\
\hline Cinsiyet & $\begin{array}{l}\text { Erkek } \\
\text { Kadın }\end{array}$ & $\begin{array}{l}164 \text { kişi } \\
132 \text { kişi }\end{array}$ & $\begin{array}{l}\% 55 \\
\% 45\end{array}$ & Yaş & $\begin{array}{l}45-70 \\
35-44 \\
25-34 \\
24 \text { ve alt1 }\end{array}$ & $\begin{array}{l}76 \text { kişi } \\
121 \text { kişi } \\
98 \text { kişi } \\
1 \text { kişi } \\
\end{array}$ & $\begin{array}{l}\% 26 \\
\% 41 \\
\% 33 \\
\% 0,1 \\
\end{array}$ \\
\hline Eğitim & $\begin{array}{l}\text { Doktora } \\
\text { Y. Lisans } \\
\text { Üniversite }\end{array}$ & $\begin{array}{c}68 \text { kişi } \\
103 \text { kişi } \\
125 \text { kişi } \\
\end{array}$ & $\begin{array}{l}\% 23 \\
\% 35 \\
\% 42 \\
\end{array}$ & Ünvan & $\begin{array}{l}\text { Öğrr.̈̈yesi } \\
\text { Öğr.Gör. } \\
\text { Arş.Gör. }\end{array}$ & $\begin{array}{l}58 \text { kişi } \\
113 \text { kişi } \\
125 \text { kişi } \\
\end{array}$ & $\begin{array}{l}\% 20 \\
\% 38 \\
\% 42 \\
\end{array}$ \\
\hline $\begin{array}{c}\text { Medeni } \\
\text { Hali }\end{array}$ & $\begin{array}{l}\text { Evli } \\
\text { Bekar } \\
\end{array}$ & $\begin{array}{l}173 \text { kişi } \\
123 \text { kişi }\end{array}$ & $\begin{array}{l}558 \\
\% 42 \\
\end{array}$ & & & & \\
\hline
\end{tabular}

Tablo-1'de yer alan demografik bilgilerin incelenmesi neticesinde analize 296 kişi katılmıştır. Katılanların cinsiyet bakımından \% 55'nin erkek ve \% 45'nin kadın olduğu, medeni hali bakımından \% 58'inin evli ve \% 42`sinin bekar olduğu, unvan bakımından \% 20`sinin öğretim üyesi, \% 38`inin öğretim görevlisi ve \% 42’ sinin araştırma görevlisi olduğu, eğitim bakımından \% 23’ünün doktora mezunu, \% 103'ünün yüksek lisans mezunu, \% 42'sinin üniversite mezunu eğitim seviyesinde olduğu, yaş bakımından \% 26‘ sinın 45-70 yaş arasında, \% 41'inin 35-44 yaş arasında, \% 33'ünün 25-34 yaş arasında ve \% 0,1'inin 24 ve altı yaş arasında olduğu tespit edilmiştir.

Yapılan analizlerde örneklem grubu rassal olarak ikiye bölünmüş ve 1. örneklemde 150 kişi, 2. örneklemde 146 kişi yer almıştır. 1. örneklem ölçeğin yapı geçerliği kapsamında açıklayıcı faktör analizinde, 2. örneklem ise doğrulayıcı faktör analizinde ve güvenirlik analizi kapsamında hesaplanması gereken istatistiklerin elde edilmesinde kullanılmıştır.

\subsection{Veri Toplama Araci}

Çalışmada Türkçe'ye uyarlanmaya çalışılan "Daha Fazla Güç Talebi Ölçeği” nin İngilizcesi ve Türkçesi çalışmanın sonunda EK-'te yer almaktadır. Söz konusu ölçek Warr vd. (1979) tarafından geliştirilmiş ve bir boyuttan oluşmaktadır. Kullanılması kolay bir ölçektir. "Daha Fazla Güç Talebi Ölçeği” nde belirlenen amacı ölçmek maksadıyla altı adet soruya yer verilmiştir. Warr vd. (1979) tarafından yapılan çalışmada, ölçeğin alfa katsayısı değerleri 0,91 ve 0,82 olarak bulunmuştur. Katılımcıların ölçekte yer alan ifadelere, her bir ifadenin karşısında "1.Hiç önemli değil", "2.Önemli değil”, "3.Önemliliği ile ilgili bir şey söylenemez", "4.Oldukça önemli" ve "5.Fazla önemli", "6.Çok önemli", "7.Aşırı derecede önemli" şeklinde verilen, 7'li sıralama ölçeği ile cevap vermeleri istenmiştir.

\subsection{Araştırmanın Sınırlılıkları}

Yapılan çalışma, anketin yapıldığı örneklem, analizin yapıldığı SPSS 23.0 paket programı, R programlama dili, Ankara ve Mersin ili, kullanılan anket formu ve eğitim sektörü ile sınırlı olup, genellemek için farklı örneklemlerde kullanılması durumunda doğrulayıcı faktör analizinin yapılması gerekmektedir.

\subsection{Uygulama Aşamaları}

“Daha Fazla Güç Talebi Ölçeği” nin Türkçeye uyarlanması üç aşamada yapılmıştır. İlk aşamada ölçeğin tercümesi yapılarak soru maddeleri incelenmiştir. İkinci aşamada ölçeğin geçerlik çalışmaları kapsamında açıklayıcı ve doğrulayıcı faktör analizi yapılmıştır. Üçüncü ve son aşamada ise ölçeğin güvenirliği ile ilgili analizler yapılarak elde edilen değerler yorumlanarak sonuca ulaşılmıştır.

Çalışmanın birinci aşamasında, ölçeğin hedef dile çevrilmesinde İngilizce ve Türkçe dillerine hâkim, ölçülen yapı hakkında bilgi sahibi Milli Savunma Üniversitesi Yabancı Diller Bölümünde görev yapmakta olan 3 öğretim görevlisi tarafından Türkçeye ve müteakiben tekrar İngilizceye bağımsız olarak çeviri ve geri-çeviri işlemleri gerçekleştirilmiştir. Tüm bu işlemler yapıldıktan sonra ölçeğin gerekli işlevi yerine getirip getirmediğini test etmek amacıyla odak grup çalışması ile bir ön test yapılmıştır. Bu işlem için uzmanlar Brislin vd. (1973) tarafından önerilen yöntemi kullanmıştır. 
Çalışmanın ikinci aşamasında, ölçeğin geçerlik çalışması (kapsam geçerliği, mantıksal geçerliği ve yapı geçerliği) yapılmıştır. Ölçeğin kapsam ve mantıksal geçerliğinin kontrol edilmesinde uzman görüşüne (Üniversitelerde örgütsel davranış alanında görevli, 10 akademisyen), yapı geçerliğinin kontrol edilmesinde ise açıklayıcı faktör analizi ve doğrulayıcı faktör analizi yöntemleri kullanılmıştır. Açıklayıcı faktör analizi ve doğrulayıcı faktör analizi yöntemlerinde kullanılan veriler, ölçeğin örneklem olarak seçilen üniversitelerde görevli 296 akademisyene uygulanması sonucunda elde edilen veriler kullanılmıştır. Örnekleme yöntemi olarak, tesadüfi olmayan örnekleme yöntemlerinden kolayda örnekleme yöntemi seçilmiştir. Ölçeğin mantıksal ve yapı geçerliğinin kontrol edilmesinde uzman kişilere sorular "1.Uygun", "2.Uygun, ama yetersiz", "3.Gereksiz" şeklinde ve ölçeğin yapı geçerliği ile ilgili analiz kapsamında katılımcılara sorular "1.Hiç önemli değil", "2.Önemli değil”, "3.Önemliliği ile ilgili bir şey söylenemez", "4.Oldukça önemli" ve “5.Fazla önemli", “6.Çok önemli”, “7.Aşırı derecede önemli” şeklinde sorulmuştur.

Çalışmanın üçüncü ve son aşamasında, ölçeğin güvenirlik çalışması yapılmıştır. Güvenirlik çalışması kapsamında Cronbach's alfa katsayısı, madde analizinin yapılması maddelere ait ortalama ve standart sapma değerleri, madde-bütün korelasyon katsayıları, madde silindiğinde ortalamalardaki ve güvenirlik katsayılarındaki değişim ve çoklu açıklayıcılık katsayısı değerleri incelenmiş ve sonuca ulaşılmıştır.

\section{7. Çalışmada Kullanılan Programlar}

Yapılan çalışmada analizler SPSS paket programı ile R programlama dilinde yapılmıştır. SPSS paket programı, açıklayıcı faktör analizi ve diğer istatistiki değerlerin hesaplamasında kullanılırken, $R$ programlama dili doğrulayıcı faktör analizi ile ilgili analizlerin ve uyum değerlerinin hesaplanmasında kullanılmıştır. R programlama dilinde yapılan analizlerde readxl, lavaan ve Hmisc paketleri ile readxl, lavaan ve Hmisc kütüphanelerinden yararlanılmıştır.

\section{BULGULAR}

\section{1. “Daha Fazla Güç Talebi Ölçeği” Geçerlik Çalışması}

Açıklayıcı faktör analizi ve doğrulayıcı faktör analizi yapılmadan önce veriler ile ilgili kontrol edilmesi gereken çeşitli varsayımlar vardır. Bu varsayımlar verilerin normal dağılıp dağılmadığının kontrol edilmesi, faktör analizine uygunluğuna belirlenmesi ve değişkenlerin birbirini yakın tahmin etme gücünün olup olmadığının ortaya konmasıdır. Bu testler ile ilgili olarak verilerin normal dağılıp dağılmadığı ile ilgili işlemler bu bölümde yapılmış, diğer işlemler ise açıklayıcı faktör analizi ile ilgili yapılan işlemler bölümünde yapilmıştır.

Verilerin normal dağılıp dağılmadığı ilgili literatürde Shapiro-Wilk, Anderson-Darling ve Jarque-Bera gibi normallik testlerinden birinin yapılması önerilmektedir (Cebeci, 2020). Bu çalışmada altı adet değişken ile ilgili normallik kontrolünde bu test ve söz konusu testin R programlama dilinde analizinde ise stats paketi ve shapiro.test fonksiyonu kullanılmıştır. Analiz sonunda iki örneklem ile ilgili olarak elde edilen sonuçlar Tablo-2'dedir.

Tablo 2. Shapiro-Wilk Normallik Testleri Sonuçları

\begin{tabular}{|c|c|c|c|c|c|}
\hline \multirow[b]{2}{*}{ Madde } & \multicolumn{2}{|c|}{ W test istatistiğ $\mathbf{i}$} & \multicolumn{2}{|c|}{ P değeri* } & \multirow[b]{2}{*}{ Test sonucu } \\
\hline & $\begin{array}{c}1 . \\
\text { örnekleme }\end{array}$ & $\begin{array}{c}2 . \\
\text { örnekleme }\end{array}$ & $\begin{array}{c}1 . \\
\text { örnekleme }\end{array}$ & $\begin{array}{c}2 . \\
\text { örneklem } \\
\end{array}$ & \\
\hline DFG1 & 0,95 & 0,894 & 0,0054 & 0,012 & Değişken normal dağılmaktadır \\
\hline DFG2 & 0,9256 & 0,784 & 0,0126 & 0.024 & Değişken normal dağılmaktadır \\
\hline DFG3 & 0,9324 & 0,85 & 0,0143 & 0,0126 & Değişken normal dağılmaktadır \\
\hline DFG4 & 0,9912 & 0,782 & 0,0000 & 0,0144 & Değişken normal dağılmaktadır \\
\hline DFG5 & 0,945 & 0,864 & 0,0042 & 0,0125 & Değişken normal dağılmaktadır. \\
\hline DFG6 & 0,9254 & 0,842 & 0,0152 & 0,022 & Değişken normal dağılmaktadır. \\
\hline
\end{tabular}

${ }^{*} p>0.05$ 
Tablo-2' de her bir ölçek maddesinin normallik testi her iki örneklemde de anlamlılık değerlerinin yer aldığı sütun incelendiğinde hepsinin anlamlı olduğu $(p>0,05)$ ve normal dağıldığı sonucuna ulaşılmıştır.

Verilerin kapsam geçerliği ile mantıksal geçerliği kapsamında uzman görüşlerinin incelenmesi sonucunda her bir sorunun Kapsam Geçerlik Oranı (KGO) değerinin 0,80 ile 0,95 arasında olduğu ve 0,05 anlamlılık düzeyinde olması gereken en düşük KGO değerinden $(0,62)$ büyük olduğu görülmüştür (Alpar, 2012). Bu kapsamda herhangi bir ölçek maddesinin çıkartılmasına ihtiyaç duyulmamıştır. Ölçeğin bütünün ve her bir alt boyutunun Kapsam Geçerlik İndeksi (KGI) değerlerinin (madde analizi sonucunda havuzda kalan maddelerin KGO değerlerinin ortalaması) ise sırasıyla 0,94, 0,89, 0,86 ve 0,96 olduğu tespit edilmiştir. Söz konusu KGİ değerlerinin literatürde 0,67 değerinin üzerinde olması istenmektedir (Alpar, 2012). Dolayısıla ölçeğin bütünü ve her bir alt boyutu ile ilgili elde edilen KGİ değerlerinin uygun olduğuna karar verilmiştir.

“Daha Fazla Güç Talebi Ölçeği” nin yapı geçerliğinin incelenmesi kapsamında açıklayıcı faktör analizi yapılmıştır. Açılayıcı faktör analizi yapılırken temel bileşenler yöntemi ile dik döndürme yöntemlerinden varimax yöntemi kullanılmıştır. Bu kapsamda SPSS 23.0 paket programında yapılan açıklayıcı faktör analizi sonucunda elde edilen analiz sonuçları Tablo-3'dedir.

Tablo 3. "Daha Fazla Güç Talebi Ölçeği” nin Betimleyici İstatistikler (1. ve 2. örnekleme grubu)

\begin{tabular}{|c|c|c|c|}
\hline Maddeler & Ortalama & Std.Sap. & N \\
\hline DFG1 & 5,41 & 1,149 & 296 \\
\hline DFG2 & 5,84 & 1,093 & 296 \\
\hline DFG3 & 5,59 & 1,040 & 296 \\
\hline DFG4 & 5,98 & 1,170 & 296 \\
\hline DFG5 & 4,65 & 1,539 & 296 \\
\hline DFG6 & 5,90 & 1,206 & 296 \\
\hline
\end{tabular}

Tablo-3'de yer alan değerler incelendiğinde, açıklayıcı faktör analizine 296 kişiden toplanan verilerin analiz edildiği, katılımcıların her bir maddeye verdiği cevapların ortalamasının birbirine yakın olduğu ve standart sapma değeri açısından ise analizde tutarlı verilerin bulunduğu görülmüştür.

Açıklayıcı faktör analizinde yapılması gereken ikinci iş, korelasyon matrisinin faktörlenebilirliğinin kontrol edilmesi gerekir. Bu kapsamda yapılması gereken Kaiser-Meyer-Olkin (KMO) değerlerine ve Bartlett's Küresellik Testi değerlerine bakmaktır. Literatürde KMO değerlerinin 0,60 değerinin üzerinde olması ve Bartlett's Küresellik Testinin anlamlılık değerinin 0,05'in altında olması arzu edilmektedir (Alpar, 2012). Bu kapsamda "Daha Fazla Güç Talebi Ölçeği" ile ilgili yapılan analiz sonuçları Tablo-4'de yer almaktadır. Açıklayıcı faktör analizinde ölçeğin yapı geçerliğinin incelenmesinde 1. örneklem kullanılmıştır.

Tablo 4. KMO ve Bartlett's Testi Sonuçları

\begin{tabular}{|c|c|c|}
\hline \multicolumn{2}{|l|}{ Kaiser-Meyer-Olkin } & 0,853 \\
\hline \multirow{3}{*}{ Bartlett's Küresellik Testi } & Ki-kare & 852,103 \\
\hline & Standart sapma & 15 \\
\hline & $\mathbf{p}$ & 0,000 \\
\hline
\end{tabular}

Tablo-4'de yer alan değerlerin incelenmesi neticesinde; KMO ve Bartlett's Küresellik Testi değerlerinin istenen referans değerleri arasında olduğu tespit edilmiştir. KMO istatistiğinin 0,853 değerine sahip olması ve Barlett testi, Ki-Kare katsayısının anlamlı $(\mathrm{p}=0,000<0,05)$ olması veri setinin faktör analizi için uygun olduğunu göstermektedir (Kalaycı, 2010: 322). Diğer bir deyişle elde edilen KMO değerine göre değişkenlerin birbirlerini yakın tahmin etme gücünün olduğunu; Barlett Küresellik Testi değerine göre değişkenler arasında yeterli oranda ilişki olduğunu göstermektedir (Durmuş, Yurtkoru ve Çinko, 2013).

Açıklayıcı faktör analizinde ölçek maddelerinin kaç faktörde toplanması gerektiğine karar verebilmek maksadıyla yamaç grafiği yönteminden yararlanılır. Bu kapsamda araştırma verileri ile ilgili olarak “Daha Fazla Güç Talebi Ölçeği" nin yamaç grafiği Grafik-1'de yer almaktadır. 


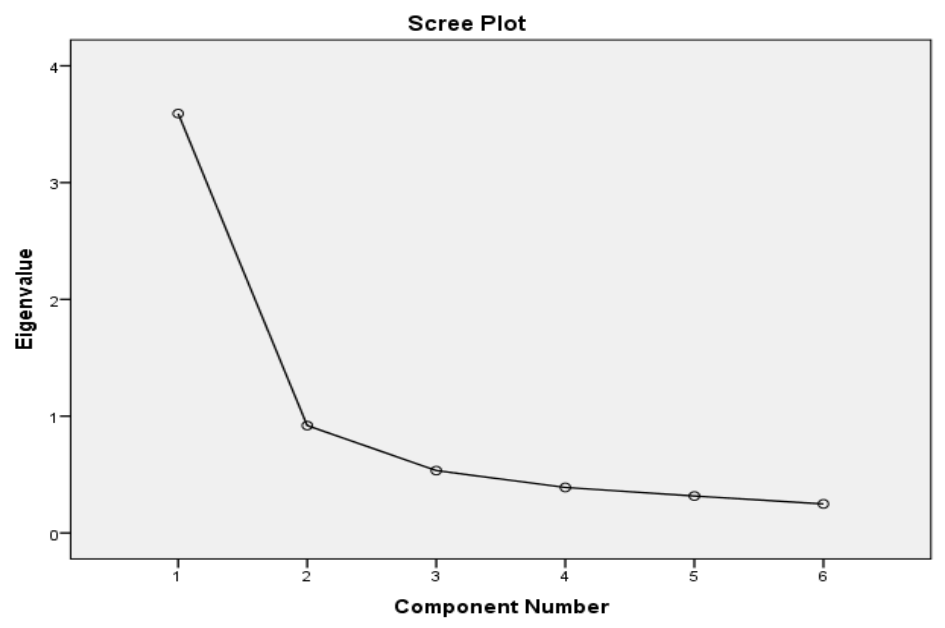

Grafik 1. "Daha Fazla Güç Talebi Ölçeği” nin Yamaç Grafiği

Grafik-1'de yer alan yamaç grafiği incelendiğinde, "Daha Fazla Güç Talebi Ölçeği” nde maddelerin tek faktör altında toplanması gerektiği sonucuna varılmıştır.

“Daha Fazla Güç Talebi Ölçeği” nde tek faktör altında toplanan maddelere ait faktör yükleri Tablo-5'de yer almaktadir.

Tablo 5. Faktörler ve Faktör Yükleri

\begin{tabular}{|c|c|}
\hline & Bileşenler \\
\cline { 2 - 2 } & $\mathbf{1}$ \\
\hline DFG4 & 0,849 \\
\hline DFG3 & 0,839 \\
\hline DFG2 & 0,831 \\
\hline DFG6 & 0,817 \\
\hline DFG1 & 0,815 \\
\hline DFG5 & 0,379 \\
\hline
\end{tabular}

Tablo-5'de yer alan faktör yüklerinin 0,379 ve 0,849 arasında değerler aldığı görülmektedir. Literatür incelendiğinde söz konusu analizde faktör yüklerinin genel olarak keşfedici faktör analizinde ölçek maddelerinin faktör yüklerinin 0,45 ve üzerinde değer taşımaları gerektiği, ancak 0,30 üzerindeki maddelerin de araştırmacının değerlendirmesine göre kabul edilebildiği ifade edilmektedir (Büyüköztürk, 2007: 118). Dolayısıyla elde edilen faktör yüklerinin değerlerinin literatürde yer alan değerlerin üzerinde olduğu tespit edilmiştir.

Açıklayıcı faktör analizinde ölçeğe ait açıklanan varyansın yüzdesine de bakılması gerekmektedir. Bu kapsamda "Daha Fazla Güç Talebi Ölçeği" ne ait açıklanan varyans değerleri Tablo-6' da yer almaktadır.

Tablo 6. Açıklanan Toplam Varyans

\begin{tabular}{|c|c|c|c|c|c|c|}
\hline \multirow{2}{*}{ Faktör } & \multicolumn{6}{|c|}{ Özdeğerler } \\
\cline { 2 - 7 } & Toplam & $\begin{array}{c}\text { \% } \\
\text { Varyans }\end{array}$ & $\begin{array}{c}\text { \% } \\
\text { Kümülatif }\end{array}$ & Toplam & $\begin{array}{c}\text { \% } \\
\text { Varyans }\end{array}$ & $\begin{array}{c}\text { \% } \\
\text { Kümülatif }\end{array}$ \\
\hline 1 & 3,591 & 59,853 & 59,853 & 3,591 & 59,853 & 59,853 \\
\hline 2 & 0,920 & 15,328 & 75,181 & & & \\
\hline 3 & 0,534 & 8,904 & 84,085 & & & \\
\hline 4 & 0,390 & 6,495 & 90,580 & & & \\
\hline 5 & 0,317 & 5,276 & 95,856 & & & \\
\hline 6 & 0,249 & 4,144 & 100,000 & & & \\
\hline
\end{tabular}

Çıkarma Metodu: Temel Bileşenler Analizi 
Tablo-6'da yer alan değerlere bakıldığında açıklanan varyans değerinin \% 59,853 olduğu görülmektedir. Söz konusu değerin daha fazla olması arzu edilmesine rağmen literatürde yapılan benzer çalışmalara göre uygun olduğu sonucuna ulaşılmıştır.

Doğrulayıcı faktör analizi, önceden belirlenen yapının ana uygulama verileri ile doğrulanıp doğrulanmadığının incelenmesinde uyum indekslerinden yararlanılmaktadır (Çokluk vd., 2016: 266). Modelin değerlendirilmesinde hangi uyum indeksinin kullanılacağı araştırmacının tercihine bağlıdır (Erkorkmaz vd., 2012: 213; Meydan ve Şeşen (2011).

Doğrulayıcı faktör analizinin SPSS'te yapılamamasından dolayı ölçeğin uyum iyiliği değerleri ile ihtiyaç duyulan diğer istatistikler $\mathrm{R}$ programlama dilinde yapılmıştır. $\mathrm{R}$ programlama dilinde de readxl, lavaan, Hmisc paketleri ve bu paketlerdeki readxl, lavaan, Hmisc kütüphaneleri kullanılmıştır. Doğrulayıcı faktör analizi kapsamında R programlama dilinde "Daha Fazla Güç Talebi Ölçeği” ile ilgili hesaplanan uyum iyiliği değerleri Tablo-7' de sunulmuştur. Ölçeğin doğrulayıcı faktör analizinde 2. örneklem grubu kullanılmıştır.

Tablo 7. “Daha Fazla Güç Talebi Ölçeği” Doğrulayıcı Faktör Analizi Uyum İyiliği Değerleri

\begin{tabular}{|c|l|c|c|c|c|c|c|}
\hline \multicolumn{2}{|c|}{ Ölçek } & $\chi^{2}$ & $p$ & SRMR* & RMSEA* & TLI* $^{*}$ & CFI* $^{*}$ \\
\hline 1 & Daha Fazla Güç Talebi Ölçeği & 54.774 & 0.000 & 0.035 & 0.026 & 0.957 & 0.95 \\
\hline
\end{tabular}

* RMSR: Root Mean Square of the Residuals (Hataların Ortalama Karakökü); RMSEA: Root Mean Square Error of Approximation (Yaklaşık Hataların Ortalama Karakökü); TLI: Tucker-Lewis Index (Tucker-Lewis İndeksi); CFI: Comparative Fit Index (Karşılaştırmalı Uyum İndeksi).

Tablo-7'de yer alan "Daha Fazla Güç Talebi Ölçeği” nin doğrulayıcı faktör analizi uyum iyiliği değerlerinin olması gereken referans değerleri arasında olduğu tespit edilmiştir (Meydan ve Şeşen, 2012, х2 için p'nin anlamlı olması, SRMR $<0,1$, RMSEA $\leq 0,08$, TLI (NNFI) $\geq 0,95$ CFI $>0,95)$ ). Doğrulayıcı faktör analizine ilişkin sonuçlar, keşfedici faktör analizi ile ortaya koyulan altı maddeli bir faktörlü yapının uygulama verileri ile doğrulandığı şeklinde yorumlanmıştır.

\section{2. “Daha Fazla Güç Talebi Ölçeği” Güvenirlik Çalışması}

“Daha Fazla Güç Talebi Ölçeği” güvenirlik çalışması, literatürde önerilen Cronbach's alfa katsayısı, ölçek maddelerine ait ortalama ve standart sapma değerleri, madde-bütün korelasyon katsayıları, madde silindiğinde ortalamalardaki ve güvenirlik katsayılarındaki değişim ve çoklu açılayıcılık katsayısı değerlerine bakılarak yapılmışır (Alpar, 2012). Bu kapsamda Cronbach's alfa katsayısı ile ilgili elde edilen istatistikler Tablo-8'de ve ölçek maddelerine ait ortalama ve standart sapma değerleri, madde-bütün korelasyon katsayıları, madde silindiğinde ortalamalardaki ve güvenirlik katsayılarındaki değişim ve çoklu açıklayıcılık katsayısı değerleri ise Tablo-9'de yer almaktadır. Ölçeğin güvenirlik analizi kapsamında hesaplanan istatistiki değerlere 2. örneklem grubu kullanılmıştır.

Tablo 8. Güvenirlik İstatistikleri

\begin{tabular}{|c|c|c|}
\hline Cronbach's Alpha Katsayısı & $\begin{array}{c}\text { Standardize Edilmiş Maddelere } \\
\text { Dayalı Cronbach's Alpha Değerleri }\end{array}$ & Madde Sayısı \\
\hline 0,834 & 0,853 & 6 \\
\hline
\end{tabular}

Tablo-8'de yer alan Cronbach's alpha katsayısı değerinin oldukça yüksek çıktığı ve söz konusu katsayının yorumlanmasında literatürde kullanılan yorumlama tablolarına göre oldukça güvenilir bir ölçek olduğu sonucuna ulaşılmıştır.

Tablo 9. Madde-Toplam İstatistikleri

\begin{tabular}{|c|c|c|c|c|c|}
\hline & $\begin{array}{c}\text { Madde Silindiğinde } \\
\text { Ölçek Ortalaması }\end{array}$ & $\begin{array}{c}\text { Madde } \\
\text { Silindiğinde } \\
\text { Ölçek Varyansı }\end{array}$ & $\begin{array}{c}\text { Düzeltilmiş } \\
\text { Madde Bütün } \\
\text { Korelasyon }\end{array}$ & $\begin{array}{c}\text { Çoklu } \\
\text { Korelasyon } \\
\text { Katsayısı }\end{array}$ & $\begin{array}{c}\text { Madde Silindiğinde } \\
\text { Cronbach's Alpha } \\
\text { Katsayısı }\end{array}$ \\
\hline DFG1 & 27,96 & 20,470 & 0,675 & 0,548 & 0,794 \\
\hline DFG2 & 27,53 & 20,751 & 0,689 & 0,581 & 0,792 \\
\hline DFG3 & 27,78 & 20,926 & 0,714 & 0,571 & 0,790 \\
\hline DFG4 & 27,39 & 19,846 & 0,728 & 0,621 & 0,783 \\
\hline DFG5 & 28,72 & 22,284 & 0,286 & 0,106 & 0,890 \\
\hline DFG6 & 27,47 & 19,728 & 0,712 & 0,565 & 0,785 \\
\hline
\end{tabular}


Tablo-9'da yer alan madde-toplam istatistiklerine bakıldığında ortalama değerlerinin birbirine yakın, madde silindiğinde Cronbach's alpha katsayısı değerlerinin literatürde önerilen 0,6 değerinin üzerinde ve diğer istatistiksel değerlerinde kabul edilebilir değerlere yakın olduğu tespit edilmiştir. Düzeltilmiş madde bütün korelasyon değerlerine bakıldığında söz konusu değerlerin 0,286 ile 0,728 değerleri arasında olduğu tespit edilmiştir. Literatürde düzeltilmiş madde bütün korelasyon değerlerinde 0,30-0,20 arasında kalan ifadeler zorunlu durumlarda kullanılabilirken, 0,20'den düşük ifadeler kullanılmamalıdır (Büyüköztürk, 2007: 118).

Ayrıca güvenirlik analizi kapsamında birleşik güvenilirlik (CR: Composite Reliability) katsayıları da incelenmiştir. Birleşme geçerliğinin doğrulanmasına faktör yükleri ve açıklanan ortalama varyans (AVE: Average Variance Extracted) değerleri kullanılmıştır. Birleşik güvenilirlik katsayılarının $C R \geq 0,70$, açıklanan ortalama varyans değerinin de $A V E \geq 0,50$ ve $C R$ değerinin AVE değerinden büyük (CR $>A V E)$ olması beklenmektedir (Hair vd., 2006; Hair vd., 2014; Fornell ve Larcker, 1981). Tablo 10'da verilen değerler incelendiğinde tüm bu koşulların sağlandığı görülmektedir.

Tablo 10. Madde-Toplam İstatistikleri

\begin{tabular}{|l|c|c|c|}
\hline & CR & AVE & $\sqrt{\text { AVE }}$ \\
\hline Daha Fazla Güç talebi & 0,910 & 0,671 & 0,819 \\
\hline
\end{tabular}

Dolayısıyla yapılan çalışmada uyarlanması yapılan ölçeğin bütün maddelerinin kullanılabileceği sonucuna ulaşılmıştır.

\section{SONUÇ VE TARTIŞMA}

Rekabetin çok şiddetli yaşandığı günümüzde işletmeler için en önemli kaynak insandır ve işletmenin başarılı olması için yöneticiler bu kaynaktan en üst seviyede faydalanmalıdır. Yenilik yapabilmek özgürlük gerektirir, verimliliği artırmak için de çalışanlar yönetim kararlarına daha fazla katılmalıdır. Bu bağlamda çalışanların veya orta kademe yöneticilerinin daha fazla güç talebi üzerinde önemle durulması gereken bir kavram olarak karşımıza çıkmaktadır. Dolayısıyla değişen koşullar çalışanlara daha fazla güç verilmesini ve daha fazla güç isteyen kişilerin istihdam edilmesini zorunlu hale getirmiş̧tir. Bu kapsamda değerlendirildiğinde Warr vd. (1979) tarafından geliştirilen "Daha Fazla Güç Talebi" ölçeğinin günümüzde de güncelliğini koruduğu ifade edilebilir.

Çalışmada, Warr vd. (1979) tarafından geliştirilen ve İngilizcesi "Higher Order Need Strength Scale" olan "Daha Fazla Güç Talebi Ölçeği” ni Türkçe'ye uyarlanması ve söz konusu ölçeğin geçerlik ve güvenirlik çalışması yapılmıştır. Söz konusu ölçeğin Türkçe'ye uyarlanması için üç aşamalı bir yol izlenmiştir. Birinci aşamada ölçek Brislin vd. (1973) tarafından önerilen yöntem ile İngilizce'den Türkçe'ye çevrilmiş, ikinci aşamada ölçeğin geçerliği ile ilgili olarak uzman personelden yardım alınarak kapsam ve mantıksal geçerlikleri ve ölçek 296 kişiye uygulanarak faktör analizi ile yapı geçerliği kontrol edilmiştir. Üçüncü ve son aşamada ise yapı geçerliğinin kontrol edildiği aynı gruptan alınan veriler ile ölçeğin güvenirliği incelenmiştir.

Ölçeğin geçerliği ile güvenirliği ile yapılan analizlerde SPSS paket program ile $\mathrm{R}$ programlama dili kullanılmıştır.

Warr vd. (1979) tarafından geliştirilen "Daha Fazla Güç Talebi Ölçeği"inde altı adet soru yer almaktadır. Warr vd. (1979), yaptığı çalışmadaki iki deney sonucunda ölçeğin alfa katsayısı değerlerini 0,91 ve 0,82 olarak bulmuştur. Yapılan çalışmada ise söz konusu ölçek ile ilgili olarak ölçeğin tek faktör yapılı olduğu, faktör yüklerinin değerlerinin 0,379-0,849 arasında bulunduğu, toplam varyansın \% 59,853'nü açıkladığı, KMO değerinin 0,853 olduğu; doğrulayıcı faktör analizinden elde edilen istatistiklere göre uyum değerlerinin Ki-kare:54,774, RMSEA:0,026, CFI:0,95, SRMR:0,035, TLI:0,917 olduğu ve hepsinin referans değerleri arasında bulunduğu tespit edilmiştir. Ayrıca güvenirlik analizinden elde edilen Cronbach's alfa katsayısının değeri 0,834 olarak bulunmuştur. Bulunan değerler ışığında, "Daha Fazla Güç Talebi Ölçeği" nin Türkiye'de sosyal bilimler alanında yapılacak çalısmalar için geçerli olduğu ve güvenilir bir şekilde kullanılabileceği sonucuna ulaşılmıştır. 
Bu çalışmanın bazı kısıtları da bulunmaktadır. Araştırmanın akademisyenlerin üzerinde yapılmış olması bu araştırmanın en önemli kısıtıdır. Bu ölçeğin çalışma hayatında kullanılabileceği öngörülmüş olmakla birlikte, diğer sektörlerde de kullanılarak sonuçlarının değerlendirilmesi gerekir.

\section{Kaynakça}

Abdel-Halim, Ahmed A., (1980). Effects of higher order need strength on the job performance-job satisfaction relationship, Personnel Psychology, 33(2), 335-347.

Alpar, R. (2012). Çok Değişkenli İstatistiksel Yöntemler. Detay Yayıncılık, Ankara.

Bekmezci, M. (2017). İş karakteristikleri teorisi içinde yönetim ve strateji 101 teori ve yaklaşım, Turunç, Ömer ve Turgut, Hakan (Eds). Siyasal, Ankara, 199-201.

Bekmezci, M. (2017). Kuşakların karşılaştııılması ve iş dünyasında ' $Y$ ' kuşağına kuramsal bir bakış, Toros Üniversitesi İ̈SBF Sosyal Bilimler Dergisi, 4(7), 101-111.

Brislin, R.W. (1970). Back-translation for cross-cultural Research, Journal of Cross-Cultural Psychology, 1(3), 185-216.

Büyüköztürk, Ş. (2007), Sosyal bilimler için veri analizi el kitabı, Pegem Akademi Yayıncılık Ankara.

Ceceli, Z. (2020), R ile Parametrik Olmayan İstatistik Analiz, Abaküz Yayınları, İstanbul

Cellar, D.F., Furst, D., Vavra, T. ve Fulton, R. (1992). Linking cognitive scripts and job design variables: The relationships between script recognition, growth need strength and intrinsic motivation, Journal of Applied Social Psychology, 22(3), 232-247.

Coleman, H.J. (1996). Why employee empowerment is not just fad, Leadership \& Organization Development Journal, 17(4), 29-36.

Çavuş, M.F. (2008). Personel güçlendirme: İmalat sanayii işletmelerinde bir araştırma, Journal of Yasar University, 3(10), 1287-1300.

Çokluk, Ö., Şekercioğlu, G. ve Büyüköztürk, Ş. (2016). Sosyal bilimler için çok değişkenli istatistik SPSS ve LISREL uygulamaları, 4. Baskı, Ankara, Pegem Akademi Yayınları.

Durmuş, B., Yurtkoru, E. S., Çinko, M. (2013). Sosyal bilimlerde SPSS ile veri analizi, (5.Baskı). Beta Yayıncılık, İstanbul.

Erkorkmaz, Ü., Etikan, İ., Demir, O., Özdamar, K., ve Sanisoğlu, S. Y. (2013). Doğrulayıcı faktör analizi ve uyum indeksleri, Turkiye Klinikleri Journal of Medical Sciences, 33(1), 210-223.

Fornell, C., Larcker, D.F. (1981). Evaluating Structural Equation Models With Unobservable Variables And Measurement Error. Journal of Marketing Research, 18 (1), 39-50.

Fried, Y. ve Gerald R.F. (1987). The validity of the job characteristics model: A review and meta analysis, Personnel Psychology, 40, 287-322.

Hackman, J.R. ve Oldham, G.R (1975). Development of the job diagnostic survey, Journal of Applied Psychology, 60(2), 159-170.

Hackman, J.R. ve Lawler, E.E. (1971). Employee reactions to job characteristics, Journal of Applied Psychology, 55(3), 259-286.

Hair, J. F., Black, W. C., Babin, B. J., Anderson, R. E., Tatham, R. L. (2006), Multivariate Data Analysis. Upper Saddle River, NJ: Pearson Prentice Hall.

Hair, J. F., Tomas, G., Hult, M., Ringle, C. M., Sarstedt, M. (2014). A Primer on Partial Least Square Structural Equations Modeling (PLS-SEM). Los Angeles: Sage.

Ivancevich, J.M. ve McMahon, J.T. (1977). A study of task-goal attributes, higher order need strength, and performance, The Academy of Management Journal, 20(4), 552-563. 
Kalaycı, Ş. (2010). SPSS Uygulamalı çok değişkenli istatistik teknikleri, Pegem Yayınları, Ankara

Kemp, N.J. ve Cook, J.D. (1983). Job longevity and growth need strength as joint moderators of the task design-job satisfaction relationship, Human Relations, 36(10), 883-898.

Lin, X.S., Qian, J., Li, M. ve Chen, Z.X. (2018). How does growth need strength influence employee outcomes? The roles of hope, leadership, and cultural value, The International Journal of Human Resource Management, 29(17), 2524-255.

Meydan H.C. ve Şeşen H, (2011). Yapısal eşitlik modellemesi AMOS Uygulamaları. Detay Yayıncılık, Ankara.

Pastor, M.C. ve Erlandson, D.A. (1982). A study of higher order need strength and job satisfaction in secondary public school teachers, The Journal of Educational Administration, 20(2), 172-183.

Robbins, S.P. ve Judge, T.A. (2012). Örgütsel davranış, Çev. Ed.: İnci Erdem, Nobel, Ankara.

Schwartz, B. (2017). Neden çalışırız?, Optimist, İstanbul.

Shalley, C.E., Gilson, L.L. ve Blum, T.C. (2009). Interactive effects of growth need strength, work context, and job complexity on self-reported creative performance, Academy of Management Journal, 52(3), 489-505.

Spector, P.E. (1985). Higher-order need strength as a moderator of the job scope-employee outcome relationship: A meta-analysis, Journal of Occupational Psychology, 58, 119-127.

Stone, E., Ganster, D. Woodman, R.W. ve Fusilier, M. (1979). Relationships between growth need strength and selected individual differences measures employed in job design research, Journal of Vocational Behavior, 14(3), 329-340.

Warr, P., Cook, J. ve Wall, T. (1979). Scales for the measurement of some work attitudes and aspects of psychological well-being, Journal of Occupational Psychology, 52(2), 129-148 
EK:

\section{Ölçeğin İngilizcesi ve Türkçesi}

\section{Daha Fazla Güç Talebi Ölçeği}

\section{İngilizce}

1. Using your skills to the maximum

2. Achieving something that you personally value

3. The opportunity to make your own decision

4. The opportunity to learn new things

5. Challenging work

6. Extending your range of abilities.

Responses: Not at all important, not particularly important, I am not sure about its importance, moderately important, fairly important, very important, extremely important

\section{Türkçe}

1. Yeteneklerimi en üst seviyede kullanmak

2. Şahsen değer verdiğim bir şeyi başarmak

3. İşimle ilgili kararlarımı kendim vermem konusunda bana fırsat sunulması

4. Yeni şeyler öğrenmem için bana fırsat verilmesi

5. Bana verilecek işlerin zorluk derecesi

6. Yeteneklerime yenilerini eklemek

Yanıtlar: Hiç önemli değil, önemli değil, önemi hakkında kararsızım, önemli, oldukça önemli, çok önemli, aşırı derecede önemli 